of the river to deal at once with any incipient signs of weakness in the banks. In the Ohio Valley, the inhabitants are being permitted to return in detachments to their houses. The total death roll, as at present ascertained, amounts to 407 , and the number of homeless is still in the neighbourhood of a million. At Louisville, several persons have been killed and a score or so injured in a series of explosions due to the ignition of an accumulation of gas in buildings following the inundation of the town.

As regards the damage done in the Ohio Valley, more accurate computation raises the figure to 527

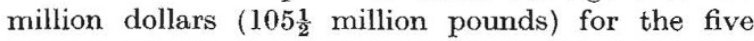
States of Indiana, Kentucky, Illinois, West Virginia and Ohio. The fund contributed to the American Red Cross for the relief of sufferers has reached a total of three million pounds and the American Senate has passed a Bill authorizing a relief appropriation of 790 million dollars (158 million pounds). President Roosevelt has sent to Congress a report of the National Resources Committee with a message advocating the sanction of a "long-range plan and policy for construction" to ensure protection for the nation from a repetition of such calamitous experiences. The scheme is estimated to cost 2,750 million dollars (550 million pounds) and would occupy a period of about six years to complete. It covers flood protection and drainage work in almost every State of the Union.

\section{Floods in France and Southern England}

THE north of France has been experiencing an abnormal amount of rainfall during the past few days which has resulted in the flooding of extensive areas of country between Dunkirk and Cassel and between Hazebrouck and Armentières on the Flanders frontier. The River Lys has overflown its bank both at Armentières and Bethune, while at Houtlines a number of dwellings have had to be evacuated. The bursting of a dam at St. Denis, north of Paris, has resulted in local flooding to a depth of five feet, and some fifty families have had to leave their homes. In southern England, after some further heavy rainfall and a resumption of the rise in the level of the Thames, the flood waters are again subsiding, and there does not seem to be further cause for alarm.

\section{A Volcano under an Ice-Sheet}

$A x$ an evening meeting of the Royal Geographical Society on February 8, Dr. Niels Nielsen gave an account of volcanic eruptions in 1934 and 1936 underneath the ice-cap of Vatnajökull in Iceland. Subglacial volcanic outbursts of this character have been known for many years from the catastrophic floods-known in Icelandic as Jökullhlaup-which result from the melting of the ice adjacent to the hot lavas and ashes, but until the investigations of Dr. Nielsen and his collaborators, no scientific accounts of these phenomena were available. It appears likely that there are at least two types of these volcanic outbursts-one, as at Grimsvötn, probably of central type, with a relatively small output of ash material but enormously energetic, forming craters in the ice; and another at Hágöngur, perhaps a fissure eruption, which produced a considerable amount of lava but so little energy that it was unable to penetrate through an ice-sheet only 100-200 metres thick. The volume of glacial melt-water liberated by the first of these volcanic outbursts was in the neighbourhood of ten thousand million cubic metres. The geological interest of these remarkable phenomena is great. Following upon the University of Glasgow geological expedition to Iceland in 1924, Dr. Martin Peacock postulated that the earlyglacial 'palagonite formation', a great series of globular basalts and tuffs which covers very extensive areas in Iceland and builds up some of the highest mountains in that island, was formed by the extrusion. of lavas under the thick Pleistocene ice-sheet. Dr. Nielsen (Geografisk Tidsskrift, Dec. 1936) has shown that rocks wholly similar to the palagonite formation have been formed in these recent eruptions, with the result that Peacock's hypothesis is now brought within the realms of established fact.

\section{Transition State in Chemical Reaction}

The thirty-sixth Bedson Lecture was delivered by Prof. M. Polanyi, of the University of Manchester, on February 1, in Armstrong College, Newcastle-onTyne. Prof. Polanyi took as his subject, "The Transition State in Chemical Reactions", and illustrated his remarks with particular reference to the ozone-oxygen reaction. Molecules are closely-packed groups linked by chemical bonds and separated by wider gaps from other molecules. The course of a chemical reaction between the molecules involves the breaking of these original chemical bonds, with the formation of new ones. During this change, the gaps between the initial molecules disappear and new ones appear between the final molecules, and between these two states there must be an infinite number of atomic configurations. At some point between the initial and final gaps separating the molecules, there is an intermediate state when no distinction can be drawn between the initial and final states. This is defined as the 'transition state of the reaction'. Turning from the purely geometric to the energy conception of the transition state, Prof. Polanyi demonstrated how the potential energy in the re. action between the molecules rises to a maximum. The position of the maximum indicates the transition state, and further, the energy of the reaction must be sufficient to surmount this energy barrier. Hence the plotting of the energy changes occurring in the reaction of two particles will indicate the transition state and the energy of activation of the reaction. Prof. Polanyi traced the evaluation of the energy changes and showed how it was possible to determine the heat of activation by application of wave mechanics and molecular constants. He also indicated how various properties of the transition state determine the changes in reaction rate caused by varying conditions such as hydrostatic pressure, change of solvent, etc. 